\title{
Morphometric study of Foramen Magnum at the base of human skull in South Gujarat
}

\author{
Roma Patel ${ }^{1}$, C. D.Mehta ${ }^{2}$

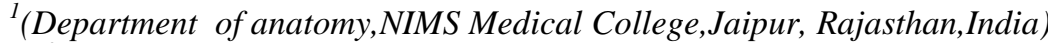 \\ ${ }^{2}$ (Department of Anatomy, Govt.Medical College,Surat,Gujarat,India)
}

\begin{abstract}
The foramen Magnum is a large opening in the occipital bone of the cranium. The dimensions of the foramen magnum are clinically important because vital structures passing through it may endure compression such as in cases of foramen magnum herniation, foramen Magnum meningiomas and foramen magnum achondroplasia. We studied one hundred dry, adult human skull of unknown sex and measured anteroposterior and transverse diameter with the help of vernier caliper. Additionally surface area of foramen magnum was also calculated. The mean antero-posterior diameter of the foramen magnum was $40.2 \mathrm{~mm}$ (range $26-40 \mathrm{~mm}$ ) and the transverse diameter was $28.29 \mathrm{~mm}$ (range $21.5-33.5 \mathrm{~mm}$ ). The mean surface area of foramen magnum was $755.37 \mathrm{~mm}$.The knowledge of dimensions of foramen magnum will be helpful radiological diagnostic procedures and neurosurgical procedures to approach in the region of Foramen Magnum. Considering above mentioned importance, this study is worthwhile.
\end{abstract}

Keywords: Foramen Magnum, skull, morphometry

\section{Introducion}

The foramen Magnum(FM) (Latin: 'great hole') is a large opening in the occipital bone of the cranium. Its transverse diameter is rather less than one third of the distance between the mastoid processes. The anterior border of the foramen magnum is formed by basilar process of the occipital bone, the lateral border by the left and right ex- occipitalis and posterior border is formed by the

supraoccipital part of the occipital bone[1].

The dimensions of the FM have clinical importance because the vital structures that pass through it may suffer compression such as in cases of FM achondroplasia [2] and FM brain herniation [3,4]. In neurosurgical practice, the transcondylar approach is commonly used to access the lesions which are ventral to the brainstem and cervicomedullary junction. It was reported that understanding the bony anatomy of the condylar region is important for this approach[5]. The knowledge of foramen magnum diameters is needed to determine some malformations such as Arnold Chiari syndrome, which shows expansion of transverse diameter[6]. In a computerized tomographic study of Catalina \& Herrera, dimensions of the foramen magnum of 63 achondroplastic individuals were compared to standards established for nonachondroplastic individuals. The size of the foramen magnum in patients with achondroplasia was small at all ages, particularly in those with serious neurological problems [7].Furthermore, Wanebo et al.[8] stated that longer FM antero-posterior dimensions permitted greater contralateral surgical exposure for condylar resection.

The diameters and area of the foramen magnum are greater in males than in females, hence its dimensions can be used to determine sex in the medicolegal conditions, especially in the following circumstances, such as explosions, aircraft accidents and war fare injuries[6,9].

So it is obvious that, FM evaluations are very important in not only to establish the most proper operational techniques, but also to obtain useful data for unknown sex estimation and determination and identity in forensic medicine. Present study was embarked on to examine the dimensions of foramen magnum.

\section{Material and method:}

100 dry human skulls were taken for observation from department of anatomy Government Medical College Surat. All skulls were adult type. The skulls that have been eroded and deformed were excluded. They were used for tutorial teaching for medical students. With the help of simple vernier caliper antero-posterior and transverse diameter of foramen magnum were measured. The length of the foramen magnum was measured from the anterior border (basion) through the centre of the foramen magnum until the end of the posterior border (opistio), The transverse diameter was measured from the point of maximum concavity on right and left margins(fig.1). 


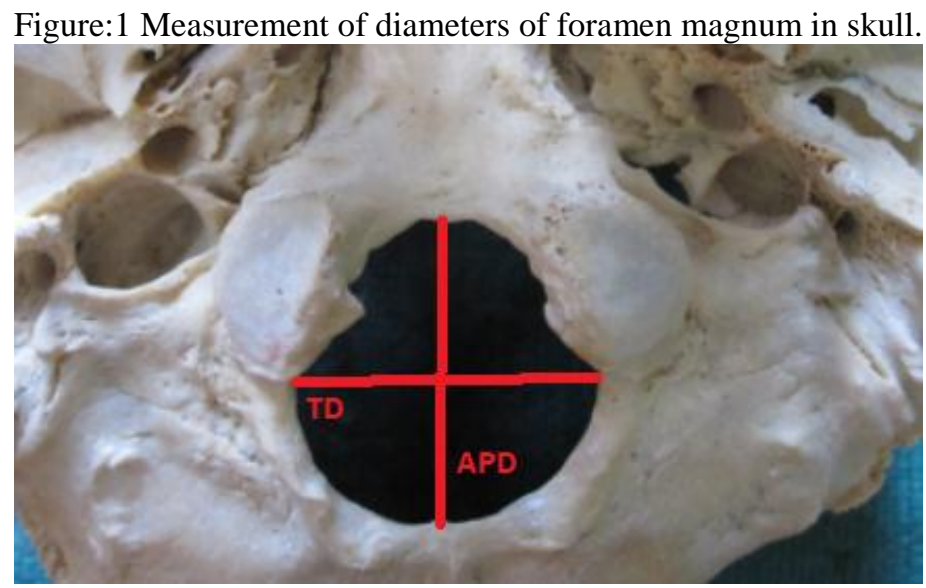

\section{Observation:}

The dimensions of Foramen Magnum are shown in Table1. Surface area of Foramen Magnum was calculated by using formula stated bellow.

$$
\begin{aligned}
& \mathrm{AREA}=\prod \times\{(h+w) / 4\} \\
& \mathrm{h}=\text { antero-posterior diameter } \\
& \mathrm{w}=\text { transverse diameter }
\end{aligned}
$$

Table: 1 Dimensions of foramen Magnum,

\begin{tabular}{|llll|}
\hline Values & $\begin{array}{l}\text { Antero-Posterior } \\
\text { diameter(mm) }\end{array}$ & $\begin{array}{l}\text { Transverse } \\
\text { diameter }(\mathbf{m m})\end{array}$ & Surface Area $\left(\mathbf{m m}^{2}\right)$ \\
\hline Maximum & 40.2 & 33.5 & 1003.27 \\
\hline Minimum & 26 & 21.5 & 480.86 \\
\hline Mean & 33.7 & 28.29 & 755.37 \\
\hline
\end{tabular}

\section{Discussion}

The dimensions of the foramen magnum are clinically important because vital structures passing through it. In present study the average antero-posterior diameter of the foramen magnum was $33.7 \mathrm{~mm}$ (range $26-40 \mathrm{~mm}$ ) and the transverse diameter was $28.29 \mathrm{~mm}$ (range 21.5-33.5).The mean surface area of foramen magnum was $755.37 \mathrm{~mm}^{2}$. Muthukumar \& Swaminathan observed that the average antero-posterior length of the foramen magnum was $33.3 \mathrm{~mm}$ (range $27-39 \mathrm{~mm}$ ) and the transverse diameter was $27.9 \mathrm{~mm}$ (range 23-32 $\mathrm{mm}$ )[5]. There is statistically significant difference between present study and observation done by Muthukumar and Swaminathan $(\mathrm{p}<0.01)$.

Tubbs RS found that the mean anteroposterior diameter was $3.1 \mathrm{~cm}$, and the mean horizontal diameter was $2.7 \mathrm{~cm}$ and the mean surface area of the foramen magnum was $558 \mathrm{~mm}^{2}[10]$.

In Catalina-Herrera's anatomic study of the FM , the diameters were $35.2 \mathrm{~mm}$ for the sagittal and $30.3 \mathrm{~mm}$ for the transverse diameter[7].Catalina-Herrera found that the means of the FM area in male and female skulls were $888.4 \mathrm{~mm}^{2}$ and $801 \mathrm{~mm}^{2}$.

Berge and Bergmann reported an average sagittal diameter of $34 \mathrm{~mm}$ and an average transverse diameter of $29 \mathrm{~mm}[11]$. In a study done on skulls of Karnataka the mean longitudinal diameter of foramen magnum in male was $33.4 \mathrm{~mm}$ and female was $33.1 \mathrm{~mm}$ and by CT Imaging method in male was $38.5 \mathrm{~mm}$ and female was $35.2 \mathrm{~mm}$. The mean transverse diameter of foramen magnum in male was $28.5 \mathrm{~mm}$ and female was $27.3 \mathrm{~mm}$ and by CT Imaging method in male was $29.1 \mathrm{~mm}$ and female was $27.6 \mathrm{~mm}[12]$. Philipp Gruber, in his study on skulls from western Europe found the sagittal diameter ranges $30 \mathrm{~mm}$ to $43 \mathrm{~mm}$ with mean of $36.6 \mathrm{~mm}$. The transverse diameter ranges from $25 \mathrm{~mm}$ to $39 \mathrm{~mm}$ with the mean of $31.1 \mathrm{~mm}$ [13]. In the Morphometric analysis of the foramen magnum in human skulls of brazilian individual in relation to gender Manoel, C. found that mean antero-posterior diameter of foramen magnum was $35.7 \mathrm{~mm}$ in male and $35.1 \mathrm{~mm}$ in female. The transverse diameter was $30.3 \mathrm{~mm}$ in male, $29.4 \mathrm{~mm}$ in female[14]. Wanebo \& Chicoine [15], in their study on cadaveric CT images measurements, found that the mean area of the FM is $820.0 \pm 100.0 \mathrm{~mm} 2$, the mean length (SD) $36.0 \pm 2.0 \mathrm{~mm}$ and the mean width (TD) $32.0 \pm 2.0 \mathrm{~mm}$.

Fatma Hayat Erdil studied fifty-four cranial CT scans obtained from the archives of Department of Radiology and observed that mean antero-posterior diameter of the foramen magnum was $35.58 \mathrm{~mm}$ and transverse diameter was $29.84 \mathrm{~mm}$. The mean antero-posterior diameter in male and female was $30.75 \mathrm{~mm}$ and $29.98 \mathrm{~mm}$ respectively. The mean transverse diameter in male and female was $36.95 \mathrm{~mm}$ and $34.41 \mathrm{~mm}$ respectively. There was a significant difference between the anteroposterior diameter of male and female 
cases[16]. Günay Y, Altinkök M.; the mean of foramen magnum area was $909.91 \mathrm{~mm}^{2}$ males, $819.01 \mathrm{~mm}^{2}$ in females which was significant $(p$ value $<0.001)[9]$.

Since the FM includes specific neuroanatomic structures [17-20] and lesions occupied in that area which need especially microsurgical intervention[20], choosing and establishing the most appropriate surgical techniques require a meticulous planning mainly based on the FM sizes to refrain from any neurological impairment $[20,21,22]$. In addition, it is quite difficult to detect many pathological situations not only by neurological examination but also needs support with the radiological findings [20,23].

\section{Conclusion}

The knowledge of diameters of the foramen magnum are needed to determine radiological malformations (Arnold Chiari's syndrome) and prior to cutting off of foramen magnum or posterior cranial fossa lesions, or sex determination of skulls. So the knowledge of dimensions of foramen magnum are important for neurosurgeons, radiologist as well as anthropologists.

\section{References}

[1]. Scheuer L, Black S. The juvenile skeleton. Elsevier, London, 2004;1-19

[2]. Hecht TJ, Horton WA, Reid CS, et al. Growth of the foramen magnum in achondroplasia. American Journal of Medical Genetics 32: 528-35, 1989.

[3]. Reich JB, Sierra J, Camp W, et al. Magnetic resonance imaging measurements and clinical changes accompanying transtentorial and foramen magnum brain herniation. Annals of Neurology 33: 159-70, 1993.

[4]. Ropper AH. MRI demonstration of the major features of herniation. J Neurol Neurosurg Psychiatry 56: 932-5, 1993.

[5]. Muthukumar N, Swaminathan R, Venkatesh G, Bhanumathy SP: A morphometric analysis of the foramen magnum region as it relates to the transcondylar approach. Acta Neurochir (Wien) 147:889-895, 2005

[6]. Sgouros S, Goldin HJ, Hockely AD, Wake MJ, et al.Intracranial volume change in childhood. J Neurosurg 1999;91:610-616.

[7]. Catalina - Herrera CJ. Study of the anatomic metric values of the foramen magnum and its relation to sex. Acta Anat 1987;130:344347.

[8]. Wanebo JE, Chicoine MR. Quantitative analysis of the transcondylar approach to the foramen magnum. Neurosurgery;49: 934-41, 2001.

[9]. Gunay Y, Altinkok M. The value of the size of foramen magnum in sex determination. J Clin foirensic Med 2000;7(3):147-49.

[10]. Tubbs RS, Griessenauer CJ, Loukas M, Shoja MM, Cohen-Gadol AA. Morphometric analysis of the foramen magnum: an anatomic study.Neurosurgery. 2010 Feb;66(2):385-8.

[11]. Berge JK,Bergmann RA. 2001. Variation in size and in symmetry of the foramina of the human skull. Clin Anat 14: 406-413.

[12]. Muralidhar PS, Magi M. MORPHOMETRIC ANALYSIS OF FORAMEN MAGNUM. Int J Anat Res 2014, Vol 2(1):249-55.

[13]. Gruber, P., Henneberg, M., Böni, T. and Rühli, F. J. (2009), Variability of Human Foramen Magnum Size. Anat Rec; $292: 1713-19$.

[14]. Manoel C, Prado FB, Caria PHF, Groppo FC. Morphometric analysis of the foramen magnum in human skulls of brazilian individuals: its relation to gender. Braz. J. Morphol. Sci 2009; 26(2): 104-108.

[15]. Wanebo JE, Chicoine MR. Quantitative analysis of the transcondylar approach to the foramen magnum. Neurosurgery;49: 934-41, 2001.

[16]. Fatma Hayat Erdil, Vedat Sabancýoðullarý, Mehmet Çimen, Oktay Ipýk: Morphometric Analysis of the Foramen Magnum by Computed Tomography: Erciyes Medical Journal,2010;32(3):167-170.

[17]. Williams PL, Warwick R. Gray.s Anatomy. Xnd edition. New York: Churchil Livingstone; 1989. p.342-361.

[18]. Snell RS. Clinical Anatomy for Medical Student. $4^{\text {th }}$ edition. Boston; Little, Brown and Company: 1992. p. 808-812

[19]. de Oliveira E, Rhoton AL Jr, Peace D. Microsurgical anatomy of the region of the foramen magnum. Surg Neurol. 1985; 24:293352 .

[20]. Coin CG, Malkasian DR. Foramen magnum. In Newton TH. Potts DG, editors. Radiology of the Skull and Brain. : The Skull. Vol 1, book 1 St. Louis: Mosby; 1971. p. 275-286.

[21]. George B, Lot G, Boissonnet H. Meningioma of the Foramen Magnum: a series of 40 cases. Surg Neurol. 1997; 47: 371-379.

[22]. Ünal F, Kýrýp T, Ýzgi N, Önal Ç, Tükel T. Mukopolisakkaridozlarýn nöropirürjikal komplikasyonlarý. Ýstanbul Týp Fakültesi Mecmuasý 1998; 61:1.

[23]. Iwata A, Murata M, Nukina N, Kanazawa I. Foramen Magnum Syndrome Caused by Atlanto-occipital Assimilation. J Neurol Sci. 1998; 154: 229-231. 